\title{
Tabularia
}

\section{Letters from the Otherworld. Arthur and Henry II in Stephen of Rouen's Draco Normannicus}

Lettres de l'Autre monde. Arthur et Henri II dans le Draco Normannicus d'Étienne de Rouen

Lettere dall' Altromondo. Arturo e Enrico II nel Draco Normannicus di Stefano di Rouen

\section{Francesco Marzella}

\section{OpenEdition}

\section{Journals}

Electronic version

URL: http://journals.openedition.org/tabularia/2858

DOI: $10.4000 /$ tabularia.2858

ISSN: $1630-7364$

\section{Publisher:}

CRAHAM - Centre Michel de Boüard, Presses universitaires de Caen

\section{Electronic reference}

Francesco Marzella, «Letters from the Otherworld. Arthur and Henry II in Stephen of Rouen's Draco Normannicus », Tabularia [Online], Autour de Serlon de Bayeux : la poésie normande aux XIe-XIIe siècles, Online since 05 April 2017, connection on 02 May 2019. URL : http://journals.openedition.org/ tabularia/2858 ; DOI : 10.4000/tabularia.2858 



\title{
Letters from the Otherworld. Arthur and Henry II in Stephen of Rouen's Draco Normannicus
}

\author{
Lettres de l'Autre monde. Arthur et Henri II \\ dans le Draco Normannicus d'Étienne de Rouen \\ Lettere dall' Altromondo. Arturo e Enrico II
nel Draco Normannicus di Stefano di Rouen
}

\author{
Francesco MARZELLA \\ Università degli Studi dell'Aquila \\ fmarzella@yahoo.it
}

\begin{abstract}
:
The poem Draco Normannicus includes a correspondence between King Arthur, now ruler of the Antipodes, and Henry II. Arthur reminds Henry of his deeds to discourage him from conquering Britanny. Henry first laughs at Arthur's letter, but then, urged by the news of his mother's death, he replies suggesting that he will hold Britanny under Arthur's suzerainty. This paper analyses these fictional letters, focusing on two main aspects, closely related to each other. 1) Intertextuality on different levels: Arthur's letter is modeled on Lucius Tiberius' letter in Geoffrey of Monmouth's Historia Regum Britanniae; Henry suggests a comparison between this correspondence and the one between Darius and Alexander; Arthur claims that the deeds he mentions are true because already told by Gildas and Geoffrey of Monmouth. 2) Political ideology: humour is not the only key to interpret the text, the purpose of the poem is not only to mock the 'Breton hope', but also to celebrate Henry II as a glorious monarch, legitimately ruling over his 'empire'.
\end{abstract}

Keywords: Stephen of Rouen, Arthurian Legend, Henry II, intertextuality, Antipodes

\section{Résumé:}

Le poème Draco Normannicus contient une correspondance entre le roi Arthur, alors roi des Antipodes, et Henri II. Arthur rappelle à Henri les hauts faits qu'il a entrepris pour lui faire renoncer à conquérir la Bretagne. Henri, dans un premier temps, se gausse de la lettre d'Arthur, mais ensuite, poussé par la nouvelle de la mort de sa mère, répond en déclarant qu'il administrera la Bretagne au nom d'Arthur.

L'article analyse ces lettres imaginaires, en se concentrant principalement sur deux aspects étroitement liés. 1) L'intertextualité sur plusieurs niveaux: la lettre d'Arthur est écrite sur le modèle de Lucius Tiberius dans l'Historia Regum Britanniae de Geoffroi de Monmouth; Henri compare cette correspondance avec celle de Darius et Alexandre; Arthur déclare que les hauts faits qu'il raconte sont vrais parce qu'ils ont jadis été narrés par Gildas et Geoffroy de Monmouth. 2) L'idéologie politique: l'humour n'est pas la seule interprétation possible du texte, le but de l'épisode n'est pas seulement de ridiculiser "l'espoir Breton", mais également de présenter Henri II comme un monarque glorieux, qui règne légitimement sur son "empire».

Mots-clés: Étienne de Rouen, légende arthurienne, Henri II Plantagenêt, intertextualité, Antipodes

Tabularia "Études», "Autour de Serlon de Bayeux...», 2017, p. 1-17, 5 avril 2017 URL: http://tabularia.revues.org/2858 | DOI: 10.4000/tabularia.2858 
Riassunto:

Il poema Draco Normannicus include una corrispondenza tra re Artù, ora re degli Antipodi, ed Enrico II. Artù ricorda a Enrico le sue imprese per farlo desistere dalla conquista della Bretagna. Enrico inizialmente ride della lettera di Artù, ma poi, spinto dalla notizia della morte di sua madre, risponde dichiarando che reggerà la Bretagna in nome di Artù.

Questo articolo analizza queste lettere immaginarie, soffermandosi su due aspetti principali strettamente connessi fra di loro. 1) L'intertestualità su più livelli: la lettera di Artù è modellata su quella di Lucius Tiberius nell' Historia Regum Britanniae di Goffredo di Monmouth; Enrico suggerisce un paragone fra questa corrispondenza e quella fra Dario e Alessandro; Artù dichiara che le imprese da lui narrate sono vere perché già narrate da Gilda e Goffredo di Monmouth. 2) L'ideologia politica: l'umorismo non è la sola chiave per comprendere il testo, lo scopo dell'episodio non consiste solo nel ridicolizzare la "speranza bretone», ma anche nel celebrare Enrico II come un glorioso monarca che regna legittimamente sul suo «impero».

Parole chiave: Stefano di Rouen, leggenda arturiana, Enrico II Plantageneto, intertestualità, Antipodi

In the $15^{\text {th }}$ century manuscript 3081 of the collection that belonged to Cardinal Ottobuoni, now in the Vatican Library (ms Reg. 3081), there survives a curious $12^{\text {th }}$ century poem entitled Draco Normannicus ${ }^{1}$. More than 4000 lines of elegiac couplets, this poem was convincingly attributed by one of its editors, Richard Howlett, to Stephen of Rouen, a monk of Bec-Hellouin, on the basis of some lines also appearing in a collection of Stephen's minor poems, preserved in a $12^{\text {th }}$ century manuscript kept in the Bibliothèque Nationale in Paris ${ }^{2}$. Not much is known about Stephen. He probably came from a noble family - his uncle being Bernard, abbot of Mont St. Michel - and entered Bec in the 1140s, later becoming deacon ${ }^{3}$. The Draco Normannicus ${ }^{4}$ is doubtless his most significant literary achievement. Relying on a number of different historical sources ${ }^{5}$ and also adding some original information, Stephen narrated events occurred from $11^{\text {th }}$ century to 1169 , celebrating the deeds of the Normans from Rollo to

1. The text of the poem in on fols. 106-158 $8^{\mathrm{v}}$. Cf. Chronicles of the Reigns of Stephen, Henry II and Richard I, 2, ed. HowLETT, 1885, p. xci-xcix, for a description of the manuscript; p. 589-762 for a critical edition of the poem. For a previous edition see Le dragon normand..., ed. Н. OмоNт, 1884. The English translation provided in Latin Arthurian Literature, ed. M.L. Day, 2005 (Arthurian Archives, XI), contains several misinterpretations.

The title given by Howlet is Draco Normannicus, but both the incipit and the explicit and the proem clearly suggest that the title is Normannicus Draco, see TATLOcK, 1933a, p. 3: "the editor has taken liberties with nothing more than its order of words and his heading for the whole".

2. See Chronicles of the Reigns..., p. x-xii.

3. On Stephen's life and career see ibid., p. xii-xvii.

4. The attribution of the poem to Stephen is proved by similarities between some expressions and phrases found both in the poem and in other Stephen's ackowledge poems. See ibid., p. x-xii.

5. Namely Dudo of St. Quentin, William of Jumièges, Robert of Torigni's life of Henry I, Chronicon Beccense, Geoffrey of Monmouth and others. See ibid., p. xviii-xxvi. 
King Henry II, who is the declared main subject of the poem ${ }^{6}$. He probably died before Becket's murder, which is not mentioned in the poem ${ }^{7}$. The poem is divided into three books, and in the last part of the second book there is an episode that has attracted the attention of many scholars. In the section describing Henry's 1167 campaign to impose his control over Brittany ${ }^{8}$ there is an unexpected epistolary exchange between King Arthur and Henry II. Here the legendary King Arthur - who according to Geoffrey of Monmouth's Historia Regum Britanniae lived in the sixth century - is presented as an eternal king now ruling over the Antipodes and first contacted by a comes Rollandus, to be identified with Roland of Dinan', one of the noble rebels of Britanny in 1167. This is by far the most famous and the most deeply investigated part of the poem, usually considered a mere mock of the Breton hope proposed by Stephen to amuse his audience; a humorous episode, a divertissement not to be taken too seriously ${ }^{10}$. Although the entertaining aspect of these lines is undeniable, I believe that humour is not the only key to understanding this surprising episode that at the same time was meant to convey political messages.

Before proposing my analysis of these contents, it is probably worth summarizing them briefly. There are four letters in total: the letter from Rolandus to Arthur (1. 947-954, chap. XVIII $\left.{ }^{11}\right)$; Arthur's reply to Rolandus (1. 955-968, chap. XIX ${ }^{12}$ ); Arthur's letter to Henry (1. 969-1216, chap. XX ${ }^{13}$ ); Henry's reply to Arthur (1. 1251-1282, chap. XXII ${ }^{14}$ ). Between the third and the fourth letter Henry comments on Arthur's letter together to his nobles (1. 1217-1250, chap. XXI ${ }^{15}$ ).

Roland, defined as consul Britonum and Arturi dapifer (steward, seneschal), wrote a brief letter to Arthur to inform him that Henry is attacking Brittany, Arthur's territory, and invoking his help and the intervention of his army to

6. For the cultural context of the Plantagenet court see Bezzola, 1963, and also Gransden, 1974, p. 187-239. On the Plantagenets and the Arthurian legend see AURELL, 2003, passim and CHAUOU, 2001, chapters I and II in particular.

7. Ibid., p. xvi.

8. On Henry II and Brittany, see Everard, 2000, p. 34-75.

9. The identification of Comes Rolandus with Roland of Dinan was suggested by Richard Howlett, cf. Chronicles of the Reigns..., p. xxii and p. 696, n. 1. See also TATLOCK, 1933b, p. 117-120.

10. Татцоск (1933a, p. 18) defines the letters in the Draco as "a light, skeptical, and humorous context". He later (TATLOCK, 1933b, p. 117) suggests the ridiculing of Rollandus through his association with a "ridiculous" Arthur as a purpose of this episode and he also states (p. 122) that the chief object of the mockery is the "Breton hope", possibly at the suggestion of Henry II himself: "the matière et sens of the episode would not only appeal to Henry the humorist but to the diplomat - its mockery of the 'Breton hope', its veiled threat to the Bretons" (p. 124). Mildred Leake DAY (1985, p. 157) writes that the Arthurian section of the poem "is a mock of the Breton hope in the light of political reality. More than that, if Henry II is compared to Arthur and is shown as Arthur's peer, yet living and Christian, Arthur is not so much mocked as Henry is honored". On the legend of Arthur's survival see also GreENE, 2002.

11. Chronicles of the Reigns..., p. 696.

12. Ibid., p. 696-697.

13. Ibid., p. 697-705.

14. Ibid., p. 707.

15. Ibid., p. 705-706. 
drive out the enemy. Arthur's reaction - which contributes to his negative characterisation $^{16}$ - is not really controlled, it is the reaction of a wild warrior or possibly of an arrogant king who sees his land under attack, as stressed by the climax of the verbs:

Hec legit Arturus, frendet, furit, aestuat ira (1. 953)

His reply is quite a reassuring one: he already knows about Henry's attempt to impose his control over Brittany and tells Roland not to worry too much, because Empress Mathilda, Henry's mother, is dying in Rouen, and the king of England will leave Brittany soon:

Impetus Henrici mihi notus, nil timeatur;

Audiet a Rodomo tristia: mater obit.

Cloto colum, Lachesis filum tenet, attrahit, occat

Atropos, et vita deserit illa quidem.

Desinet hic Britones, nec quibit ferre dolorem,

Nam nihil in mundo carius extat ei. (1. 957-962)

In any case Arthur decides to write a letter in order to make it clear that he will defend his people if ever Henry decides to attack. In his letter to Henry, Arthur introduces himself as "Arturus magnus, fatorum lege perennis" (1. 969), condemns Henry's attempt, claims to be greater than a long list of rulers and warlords of the past (the Assyrian Sennacherib, Nebuchadnezzar, Alexander, Caesar ${ }^{17}$, Constantine, Charlemagne, Rollo, William the Conqueror). Then he remembers his deeds against Lucius Hiberius - the Lucius Tiberius of Historia Regum Britanniae - and the Roman army he faced when he conquered Gaul. The account of the war - based on Geoffrey's Historia and from 1.1039 told by Arthur in the third person (e. g. "Arturus... advolat...", "Arturus praeparat...", "Arturus mandat..." "Audiit Arturus..." etc.) - is given in detail and constitutes the largest part of the whole Arthurian section of the Draco, nearly 140 lines (1. 1003-1140). Arthur goes on by remembering Mordred's treachery and how he was mortally wounded (1. 1141-116o). At this point Stephen demonstrates that he knows more than Geoffrey did about Arthur's fate: his Arthur was brought to Avalon - an epilogue he possibly found in Geoffrey's Historia Regum Britanniae or even Vita Merlini - where he was healed and made immortal by his sister Morgan to become - and this is the most original feature of Stephen's narration - eternal king of the inferior mundus, the Antipodes:

16. On Arthur as tyrant king and anti-hero see ECHARD, 1998, p. 91.

17. The couplet "Nec radians armis, quem primum pertulit Anglus, / Romulidum virtus ingeniique decus" (1. 993-994) clearly refers to Caesar. Mildred Leake Day (Latin Arthurian Literature, p. 241) unexplainably suggests to identify the radians armis with Odoacer and proposes an unacceptable translation of these lines: "Nor the Angle in gleaming arms, whom valor proclaimed / to be the first Roman noble by nature". 


\author{
Saucius Arturus petit herbas inde sororis, \\ Avallonis eas insula sacra tenet. \\ Suscipit hic fratrem Morganis nympha perennis, \\ Curat, alit, refovet, perpetuumque facit. \\ Traditur antipodum sibi jus; fatatus, inermis, \\ Belliger assistit, proelia nulla timet. \\ Sic hemispherium regit inferius, nitet armis, \\ Altera pars mundi dimidiata sibi. \\ Hoc nec Alexandri potuit, nec Caesaris ardor, \\ Ut superum tellus sic sua jura ferat. \\ Antipodes hujus fatalia jura tremiscunt; \\ Inferior mundus subditus extat ei. \\ Evolat ad superos, quandoque recurrit ad ima \\ Ut sua jura petunt, degit ubique potens. (1. 1161-1174)
}

Arthur, foreseeing a war between the king of England and the king of France, exhorts Henry to retreat and informs him that he has already left the Antipodes with his fatata cohors, impenetrabilis armis. Passing through the Cyclades, facing the Indians, Parthians and Arabs, Arthur's fleet arrived in Cornwall, where the eternal king decided to stop and wait, ready to declare war if Henry disobeys (1. 1189-1216).

After reading Arthur's words, far from being frightened, Henry laughs and turns to his nobles to propose a comparison with Darius' threatening letter to Alexander the Great, suggesting that the risk for Arthur, a new Lazarus, is that he will die in the woodland as Darius did. He decides to write to Arthur ne se contemni reputet (1. 1249), mitior is forsan vi rationis erit (l. 1250). He seems to dismiss Arthur's threat from a position of superiority. Nevertheless he writes a respectful but clear letter stressing Arthur's greatness and defending his rights at the same time: both Neustria and Brittany were under the control of Rollo and Henry inherited them de jure (1. 1263-1266). He will accept Arthur's proposal only because his mother Mathilda has died. He will obey ad tempus though, because Britanny must be returned to him and his sons, and he will hold it under Arthur's authority (1. 1273-1282).

The second book ends with the news of Mathilda's death brought to Henry by a monk of Bec, possibly Stephen himself ${ }^{18}$, and the description of the close relationship between the English king and his mother.

Previous scholarship has mainly focused on the way Stephen reshaped the Arthurian legend, adding new otherworldly developments and mocking the hopes of the Bretons ${ }^{19}$. In this paper I would like to discuss others features of

18. As suggested by Richard Howlett in Chronicles of the Reigns..., p. lxxix and p. 708, n. 2. See also TATLOCK, 1933b, p. 124.

19. For the main contributions on Stephen's treatment of the Arthurian legend, see Loomis, 1941; TATLOCK, 1933a and 1933b; Moretti, 1993. 
this intriguing text that I think still deserve more attention: intertextuality on different levels and political ideology.

\section{The Arthurian legend in the Draco Normannicus}

Before starting this analysis, it is still useful to discuss briefly some aspects of Stephen's treatment of the Arthurian legend.

1) Stephen relied on more than one source. His declared sources are Geoffrey's Historia - on which he depends for the story of Arthur's war with Rome and of the final battle against Mordred - and Gildas. In his letter to King Henry Arthur claims that everything he says about his deeds is true and invites anyone who wants to know more about his deeds to read:

Quae Monumetensis uera loquendo canit. (1. 1178)

Arthur adds that his main battles are numbered as twelve in the book written by Gildas the Wise:

Dinumerat mea bella, liber Gildae sapientis

Cum duodena refert, maxima sola notat. (1. 1179-1180)

Here Stephen clearly confuses Gildas with Nennius, in whose Historia Brittonum the famous list of battles can be found ${ }^{20}$. Stephen could find the reference to Avalon in Geoffrey's Historia, but it cannot be precluded that he had the chance to read about Avalon also in Geoffrey of Monmouth's Vita Merlini (1. 929-940). He may have been able to read a copy of this poem in Bec. But there is still something that does not seem to derive from any known text: the idea of Arthur as king of the Antipodes. This kingdom, as we will see, has hellish characteristics and Stephen possibly derived this pattern from oral tradition, genuine legends independent from the ones known to Geoffrey. A clue of the genuineness of these sources could be the fact that Arthur here is clearly a pagan ruler, healed and resurrected to an eternal life by the magic of his sister, while Geoffrey's Arthur is a Christian king who has an image of the Virgin Mary painted upon his shield. This could mean that here we have a pre-Christian version of the legend and I think there is no need to suppose that Stephen would have 'converted' his Arthur to paganism only to oppose him to the Christian King Henry (even though this opposition is evident, as we will see ${ }^{21}$.

20. Historia Brittonum, $\S_{56}$, see, La Légende arthurienne, FARAL (ed.), t. 3, 1929, p. 38-39.

21. Arthur's paganism is particularly stressed in DAY, 1985, p. 154-155. Among other clues of Arthur's pagan faith, Day mentions his reference to the Fates in 1. 959-960: even though I agree with the idea that Stephen presented Arthur as pagan ruler of the Otherworld opposed to the Christian Henry II, I believe that this specific reference to the mythological characters known as Parcae could be due just to Stephen's manneristic imitation of the style of classical epic. 
2) This legend probably came from the continent ${ }^{22}$. While traditionally remembered as king of Britain, in the Draco Arthur is primarily lord of Brittany ${ }^{23}$, the first of his three crowns is the crown of Brittany:

Substravi Britones armis, Anglosque subegi,

Francorum domui turgida colla jugo. (1. 981-982)

Here, as in other lines of the poems (e. g., II, 968), the Britones are certainly the inhabitants of Brittany. There might possibly be a connection between this legend of Arthur as eternal king of the Otherworld told in the North of France and the one that inspired the representation of Arthur riding a ram in the $12^{\text {th }}$ century mosaic of the Cathedral of Otranto, in Southern Italy, a territory ruled by the Normans. As scholars have noticed ${ }^{24}$, here too Arthur seems to have the role of a (possibly negative) king of the Otherworld ${ }^{25}$. Another similar tradition wants Arthur to rule over a otherworldly kingdom under mount Etna, in Norman Sicily, as is mentioned by Gervase of Tilbury ${ }^{26}$.

3) The Antipodes ruled by Arthur are a mysterious land. They are a mundus inferior located in the hemispherium inferius, in the altera pars mundi opposed to the superum tellus. Arthur can move from the lower world to the upper (Evolat ad superos..., 1. 1173-1174). The exact location of this world is not clear. On the one hand it might appear similar to the ancient notion of the Antipodes, the southern hemisphere where people walk upside-down; this idea seems confirmed by the odd itinerary followed by Arthur to reach Cornwall (Cyclades, India, Parthia and Arabia). But at the same it seems to have the characteristics of an underground world opposed to our world, a fairy world or the world of the dead. Its king is fatorum lege perennis (1. 969) and fatatus (1. 1165), its rights are fatalia iura (l. 1171), its army is a fatata cohors, impenetrabilis armis (l. 1197): this is a supernatural kingdom in which are probably merged both the idea of a fairy underworld and the Celtic idea of a far island of the dead ${ }^{27}$. I think that what John Carey wrote about the connection between Celtic Otherworlds and the medieval erudite idea of Antipodes might apply to our text: "The supernatural realm which the gods inhabited - the 'Otherworld' of modern scholarship - was thought to be immanent everywhere, but most often accessible by going underground

22. TATLOCK, 1933b, p. 117 and p. 122, n. 7.

23. Chronicles of the Reigns..., p. xxii.

24. See Loomis, 1941, p. 300-301.

25. On positive and negative connotations of King Arthur see Aurell, 2007a, p. 226-229 and p. 233234.

26. Gervase of Tilbury, Otia imperiala. Recreation for an Emperor, ed. and trans S.E. BANks and J.W. Binns, 2002, p. 334-337; Loomis, 1941, p. 297-299; see also Pioletti, 1989, p. 6-35.

27. TATLOCK, 1933b, p. 113-117 and Loomis, 1941, where Loomis, always concerned about Celtic sources, tries to explain that the connection between Arthur and this otherworldly realm could go back to a traditional belief and should not be considered an invention of Stephen, as suggested by J.S.P. Tatlock. See also Krappe, 1944 and Moretti, 1993, p. 443-450. 
or underwater: the lower hemisphere, a habitable region which was described as lying either 'sub terra' or 'sub aquis', could serve as a rationalization of the subterranean land of the immortals" 28 .

\section{Intertextuality in the Draco Normannicus}

Even though this sudden and striking appearance of Arthur in the middle of an account of historical events of the $12^{\text {th }}$ century might surprise the modern reader, this is not the only occurrence of Galfridian matter in the poem. On the contrary, Stephen constantly refers to Geoffrey's work. The first reference is in the title of the poem, reported in both incipit and explicit. Although misinterpreted as 'standard' by the editor Richard Howlett ${ }^{29}$, as John Tatlock convincingly pointed out ${ }^{30}$, the word Draco hides a link to one of Merlin's prophecies reported by Geoffrey, the prophecy foreseeing the Saxon invasion of Britain as the rise of a Germanicus Vermis. But the prophetic words of Merlin linger throughout Stephen's lines, indissolubly linking the rise of the Normans, and of Henry II in particular, to the legendary past of Britain. Some examples. The marriage of Mathilda and the Emperor Henry V fulfils Merlin's prophecy about the nesting of the eagle:

Hic aquilam uatis nidificare uides (b. I, 1. 172)

According to Stephen, Merlin foresaw also the drowning of her brother William (b. I, 1. 233-234) and referred to Henry I as a lion (b. I, 1. 239 ff.); Eleanor, firstly wife of Louis VII and then of Henry II, is the eagle that broke the pact (b. I, 1. 297; II, 116; III, 1319), and most of all Henry instead is the wild boar (I, 359-36o) ready to rule over England after the death of King Stephen:

Montibus instat aper galeati transuolat umbram,

Merlinus merulae uocibus ista canit $^{31}$.

The use of Merlin's prophecies in Stephen's epic can be seen as in a way comparable to what Aelred of Rievaulx did dealing with a completely different literary genre. In his Vita sancti ÆEdwardi regis et Confessoris Aelred interpreted

28. CAREY, 1989 , p. 6

29. Chronicles of the Reigns..., vii, n. 1: "The word Draco here of course means 'standard".

30. TAтLOCK, 1933a, p. 3-4: "It is true that an image of a dragon was used by many peoples, especially English, as a military ensign, but its appropriateness here would be dubious. The words, in Stephen's order, are imitated from the precise part of the Prophecies of Merlin which he borrowed so much from all through - "exurget Germanicus Uermis," "coronabitur Germanicus Uermis," "vix obtinebit cauernas suas Germanicus Draco.” These expressions mean the Saxons. Normannicus Draco is merely a taking phrase for the Normans, whose ruling house is the chief subject of the poem. The fact that no interpretation of the title is given in the poem probably shows that Stephen assumed his readers' familiarity with the Prophecies". Nevertheless, DAY, 1985, p. 154, writes: "Draco in the title is usually interpreted as 'standard' not 'dragon". But see also Latin Arthurian Literature, ed. Day, 2005, p. 48.

31. About the use of Merlin's Prophecies in the Draco see Tatlock, 1933a, p. 3-5. 
the last prophecy pronounced by the Anglo-Saxon king from his deathbed suggesting that the dying ruler was foreseeing the accession of Henry II, the cornerstone of the Norman and Anglo-Saxon people ${ }^{32}$. What Aelred and Stephen have in common is the attempt to legitimize Henry through the use of prophecies that link him to the past of Britain and Brittany, respectively.

It must be noted that the Arthurian episode appears in the second half of the second book of the Draco and that in the third book there is only one reference to Merlin and his prophecies (III, 1319). The Prophetiae Merlini, included in the Historia Regum Britanniae, work here as an hypotext ${ }^{33}$ of the Draco and quotations and reminiscences of Geoffrey's text seem to prepare Stephen's audience for the appearance of the Galfridian hero par excellence: King Arthur. His appearance is anticipated by a brief and apparently insignificant mention in book I, 668. Rollo is burning Nantes and Arthur is not aware of it: Arturus nescit ista geri. The writer seems to suggest that if he knew what was going on he would have done something about it. Stephen is preparing his audience for the Arthurian section in book II $^{34}$. This must be considered not just the most extravagant episode of the poem, but also the (not only literally) central one. As already noticed, Stephen so much enjoys playing with intertextuality that he even makes his Arthur invoke the authority of Geoffrey (and Gildas) to prove the veracity of his deeds. One might wonder how a medieval audience would react to the idea of a fictional character (if this was intended) suggesting that they should read the work of the writer who wrote widely about him while appearing in a new text: the oddity certainly does not go unnoticed by the modern reader.

Stephen is even eager to quote directly from the Historia Regum Britanniae. The opening lines of Arthur's letter to Henry are:

Arturus magnus, fatorum lege perennis,

Henrico iuueni, quod meruisse putat. (II, 969-970)

This recalls the opening sentence of another letter, the one sent by Lucius, procurator of the Roman Republic to Arthur in the Historia when the British king's presence in Gaul was perceived as a threaten for Rome: "Lucius, rei publicae Romanae procurator, Arturo regi Britanniae, quod meruit" 35 . It is clear that Stephen here is not simply re-using a formula he knew and could fit his text, if we consider that the war between Arthur and Lucius is one of the main topic of Arthur's letter. There is probably something more behind it.

Intertextuality in the Draco does not involve only Arthurian texts. Arthur's epistula is explicitly compared also to another famous letter. When commenting on Arthur's message with his nobles, Henry suggests the idea that Arthur is

32. See Aelredi Rievallensis Opera Omnia VII, ed. Francesco MARZELLA, 2017, p. 154-155.

33. GenetTe, 1997, p. 5.

34. See TATlOCK, 1933a, p. 6.

35. Ibid. 
behaving with him like Darius did with Alexander. He gave to Alexander, disguised as a poor stranger, a letter to be delivered to the Macedonian king. When Alexander reads the letter with his companions he laughs at Darius' threats. The risk for Arthur is to end like Darius did: killed by Alexander while escaping in the woodlands after the battle.

There is no need to recall here the great prominence of the figure of Alexander in the Middle Ages ${ }^{36}$. Stephen, probably relying on the $10^{\text {th }}$ century Leo the Archpriest's Vita Alexandri ${ }^{37}$, mentions him more than once ${ }^{38}$. In his letter Arthur compares himself to Caesar and Alexander (1. 1169-1170 ${ }^{39}$, affirming that he is even greater than them since he rules also in the lower hemisphere. Stephen wittily makes his Henry confidently overturn the comparison (l. 1235): Arthur is not Alexander, he is Darius, the arrogant king destined to lose; Henry himself is the new Alexander who laughs at the threats of the enemy, the king who will win and most of all the king who wants to build an empire ${ }^{40}$. The switch in this comparison is made explicit by Stephen through Henry's words, but there is also a similar less explicit case. As we saw, the first lines of Arthur's letter echo the opening lines of Lucius' letter in the Historia. But Geoffrey's Arthur is the addressee of the letter, the one who is challenged to battle because in building his empire he constitutes a danger for the already existing Roman empire. Stephen's Arthur instead is the one who sends these words of anger and challenge and Henry is the addressee, the new ruler who is expanding his supremacy. The roles are inverted: Arthur represents the old and Henry is the new, the first the arrogant king who threatens war and the second is the one who with his deeds is scaring the lord of the old empire. Henry is not only a second Alexander, he is also the new Arthur whose accession was foreseen by Merlin the prophet, the new aper or leo who will substitute the Cornubiae aper.

The purpose of this unique episode becomes clear and it does not consist only in amusing the audience, possibly including Henry II himself. The celebration of the Plantagenets is the main subject of the poem and Stephen states it clearly in the proemium:

Henrici juvenis, praeclari regis in armis

Materiae causam vita thronusque dedit (1.57-58)

A way that Stephen uses to celebrate Henry's "life and throne" is to implicitly compare him to the hero of Geoffrey's Historia. The relationship between Henry and Arthur is close, as other details reveal. As we have already

36. See e. g. Boitani, 1997.

37. See Tatlock, 1933a, p. 8. According to Howlett instead (Chronicles of the Reigns..., p. 705, n. 1) the story of Alexander and Darius, already told in the Romance of Alexander the Great by Pseudo-Callisthenes, could be drawn from Julius Valerius' Res Gestae Alexandri Magni, II, 26.

38. Chronicles of the Reigns..., I, 363, 1389; II, 977, 991-992, 1219, 1222, 1227; III, 1123.

39. On Arthur and Alexander see Boutet, 1992.

40. VAn Houts, 2006, p. 59: "In the eyes of Stephen, the Empress's unicus filius, Henry II, was the equal of Arthur and Alexander on a scale that was truly imperial". 
seen, the most significant change made by Stephen to Geoffrey's narration is to present Arthur firstly as king of Brittany. A concept reaffirmed often in the episode is actually that Arthur is king of three nations: Brittany, England and France. Roland addresses his letter Arturo regi trino (1. 947); Arthur writing to Henry claims:

Substravi Britones armis, Anglosque subegi,

Francorum domui turgida colla iugo.

Sic triplicis regni diademata tunc tria gessi

Solus, in his terris par mihi nemo fuit. (1. 981-984)

Henry clarifying to his nobles that he knows Arthur's deeds and acknowledges his greatness remembers how he was king of three nations:

Rex Britonum, rex Anglus erat, rex Francicus idem

Scimus plura quidem subdita regna sibi. (1. 1239-1240)

But Arthur is not the only rex trinus. In book I Stephen writes about Charlemagne:

Francos, Romanos, Alamannos possidet unus;

Unica vis unum sic tria regna facit. (1. 567-568)

And in book III:

Francicus en princeps Alamannicus Italicusque,

Sic tria sceptra regit, sufficit ipse tribus. (1. 717-718)

Karolus post imperialis

Romolidum princeps jam tria regna tenet

Italicus, Francus, Alamannicus extat in unum,

Dum Karolus vivens, haec tria sceptra regit. (1. 1167-1170)

And even if Stephen does not say it, his audience might remember that Alexander is traditionally considered a kind of rex trinus, ruling over the three parts of the world: Europe, Asia and Africa ${ }^{41}$. Possibly Henry II, even if not strictly speaking king of three nations, can figure in this list. As he answers to the King of Antipodes he remembers that he inherited Brittany and Neustria, obtained by Rollo - as Stephen tells in the first book - and of course he rules also over England ${ }^{42}$. When in book I Stephen describes Henry crossing the sea

41. Moretti, 1993, p. 449-450.

42. On Henry's other titles in the poem see HARris, 1994, p. 116: "During his reign, Henry II presented himself variously as King of England, Duke of Normandy and Aquitaine, Count of Poitou and Anjou: his coinage and charters testify to a division of titles and powers, and his behaviour to 
to become king of England he calls him alter Julius (I, 311) - as William the Conqueror is called in the Carmen de Hastingee Proelio ${ }^{43}$ - and later he celebrates Henry as:

Iulius in terris, Macedonis astat in armis Exprimit iste duos sensibus, ense, manu.

Nec minor eloquio, vi mentis, culmine morum,

Ortu, divitiis, nobilitate ducum ${ }^{44}$. (I, 363-366)

Stephen goes on saying that although the lands controlled by Henry cannot be compared in terms of the extension to the ones conquered by Alexander and Caesar, the Plantagenet is better than them for a different reason:

Mundi pars minor huic, fidei sed lucet refulgent:

Hac superatur ab his, hac superavit eos. (I, 367-368)

This is the same argument that concludes Henry's letter to Arthur: his immortality is greater than Arthur's because his is granted by the law of Christ. Arthur claims to be more important than Caesar and Alexander, Henry is greater than Arthur.

\section{The political message}

Alexander, Caesar, Arthur, Charlemagne: the most eminent rulers of all times, the builders of new empires. We have already discussed the list of rulers that Arthur dismisses as less important than him: that list starts with Sennacherib and ends with William the Conqueror. It hides a completely different message: there is a connection between the Norman rulers and the most important kings and emperors of the past. Stephen, who wants to celebrate the Norman dynasty, seems to suggest that his hero completes that list and that his empire is similar to the greatest empires of history and possibly overshadows them.

The real term of comparison for Henry is certainly not the King of the Antipodes, but the King of France, who also seeks to control Brittany. Arthur predicts a war between the two and his prophecy seems to be confirmed by the prodigies that occurred after Mathilda's death (III, 141-175). In the third book Henry is shown as reluctant when King Louis, of whom he is paradoxically the most powerful vassal, orders him to swear loyalty. He does not consider himself inferior to anyone:

acceptance of Louis VII's sovereignty on the continent. In the Draco, however, Henry II's lands are welded into a single imperium, which he rules as rex Anglorum".

43. TERLIZZI, 2015.

44. Also William's fleet is considered better than Caesar's in I, $1387 \mathrm{f}$. 
Denegat ille ferus ulli se subdere regum,

Impar nec cuneis par diadema nitet. (1. 179-180)

Louis, and not Arthur, is his real enemy, and this time Henry does not laugh at the request of his opponent, he is ferus instead ${ }^{45}$. Henry, opposed to Stephen's Arthur, is like Geoffrey's Arthur who did not want to pay the tribute due to Rome. And therefore there must be a clear reason why the main episode from the Historia retold by Stephen is Arthur's war against the Roman Empire in Gaul. The idea of empire recurs in the words emperor Frederick Barbarossa referred to Henry II by the duke of Saxony, sent on an embassy by the emperor, and it is meant to diminish the common enemy, Louis ${ }^{46}$. Barbarossa, whose words are reported by the duke of Saxony, first suggests that Henry should not submit himself to Louis because he is not inferior to the king of the Franks:

\footnotetext{
Mandat ne regi Francorum subiciatur.

Cum sibi par virtus, par honor atque thronus:

Non par at major, patrios si jure thriumphos

Inspicit, ac proprii culmina tanta throni.

Foedera si pacis ineat, conservet honorem

Tum sibi tum natis consulibusque suis.

Imperium natis nitatur pacificare,

Desidis est regis subdere colla jugo. (1. 235-242)
}

The emperor adds that Louis is just a king and not an emperor, because he is the descendent of Hugh Capet, not of Charlemagne:

\author{
Hugonis fuit hic, Karoli non ipsius heres, \\ Heredes Karoli depulit ille dolo. \\ Ejus progenies regni pellatur ab arce \\ Ut sibi par ratio, jus sibi constet idem. \\ Translatum regnum transferri jure valebit; \\ Bellica vis tollat quod tulit ipse dolus. \\ Ecclesiam turbans, populi vastator et ustor, \\ Nec sibi nec regno proficit, immo nocet. \\ Regis nomen habet, reges non destruat ergo ${ }^{47}$ : \\ Destructor patriae sedis ab arce ruat. (1. 247-256)
}

After this explicit criticism of Louis' behaviour, Barbarossa states clearly that he is the only rightful heir of the Holy Roman Empire:

45. HARRIS, 1994, p. 115: "What particularly vexed Stephan of Rouen was the erosion of Normandy's independence vis-a-vis the French throne".

46. On Stephen's anti-Capetian attitude see ibid., p. 121-124 in particular.

47. The reading in the manuscript is "regnis non destruit". 
Heredem Karoli se fatur, Francigenarum

Viribus imperii querit habere thronum.

Jus Karoli jus ejus erit, perquiret ubique

Quod lex, quod ratio, quod sibi jura dabunt. (1.257-260)

Louis, the descendant of a usurper, is only a king, and Henry, who rules over an imperium, should not consider himself inferior to him, relying on the alliance with the emperor, who even offers the throne of France to Henry's heir $(1.261-264)^{48}$.

\section{Conclusions}

Going back to the Arthurian episode, whose importance is given especial prominence by its close proximity to the central episode of Mathilda's death, one might wonder why Henry agrees to hold Brittany under Arthur's authority, even if ad tempus. This is probably the solution Stephen imagined as being necessary to allow him to continue his story without the embarrassment of narrating an imaginary battle between his main character and the fatata cohors of the evanescent King of the Antipodes. In this way he could make his fictional narration match real history and fit it with Henry's decision not to prosecute his campaign. After all the Normannicus Draco can still be labelled as a historical epic ${ }^{49}$, even though of a very unusual kind ${ }^{50}$, and it does not include any other long narratives dealing with the supernatural. The Arthurian episode is the exception and therefore it is even more significant. It is the central section of the poem in which Stephen, resorting to intertextuality (with reminiscences, references and quotations), presented Henry II as the perfect ruler able to overcome Alexander and most of all Arthur, Stephen did something comparable to what Walter Map did in his De Nugis Curialium $(\mathrm{I}, 12)$ by jokingly suggesting that Henry supplanted the Briton King Herla whose constant wandering was transferred to the Plantagenet, whose curia is frequently moving to different places of his kingdom. The main difference between Stephen and Walter is that the former is not joking: the epistolary exchange between Arthur and Henry can be considered amusing and entertaining, but its primary purpose was to convey a powerful political message that could please the king, to whom

48. In book III there are other references to the Roman and Holy Roman empire also in Antipope Victor IV's speech (1. 677 ff.) and in Pope Alexander III's speech (1001 ff.), mainly dealing with the problematic relationship between the Empire and the Church. The importance of the idea of empire in the Draco is mentioned in KuHL, 2014, on p. 427, 429-431. See also VAN Houts, 2006, p. 58: "Stephen wrote the Draco Normannicus to legitimize Henry II's imperial policies".

49. As in Manitius, 1931, p. 690.

50. For a different opinion, cf. HARRIs, 1994, p. 114: "Certain other characteristics, however, tell against regarding the Draco as an epic. To begin with, the poem is in elegiacs, which is not the metre appropriate for epic. (...) what argues against classifying the Draco as an epic is the polemical nature of the poet's discourse". The first argument is particularly weak since epic poems were written also in elegiac couples at least since the Carolingian age. 
Stephen was known and to whom our poet possibly intended to present his intriguing work, well deserving of new scholarly attention ${ }^{51}$.

\section{Bibliography}

\section{Sources}

Aelredi Rievallensis Opera Omnia VII - Vita Sancti Ædwardi regis et Confessoris, ed. Francesco Marzella, Turnhout (CCCM 3A), 2017, p. 154-155.

Chronicles of the Reigns of Stephen, Henry II and Richard I, ed. Richard Howlett, London, Longman (Rolls Series 82), vol. 2, 1885.

Geoffrey of Monmouth, Vita Merlini / Life of Merlin, ed. and trans. Basil Clarke, Cardiff, University of Wales Press, 1973.

Gervase of Tilbury, Otia Imperialia / Recreation for an Emperor, ed. and trans. Shelagh E. BAnks and James W. Binns, Oxford, Clarendon Press (Oxford Medieval Texts), 2002.

Latin Arthurian Literature, ed. and trans. Mildred Leake DAY, Cambridge, Brewer (Arthurian Archives, XI), 2005.

Le dragon normand et autres poèmes d'Étienne de Rouen, ed. Henri Omont, Rouen, Librairie Charles Métérie, Société de l'Histoire de Normandie, 1884.

Nennius, Historia Brittonum, in La Légende arthurienne. Études et documents. Les plus anciens textes, Edmond Faral (ed.), t. 3, Paris, Champion, 1929, p. 1-62.

Stephen of Rouen, Normannicus Draco, in Chronicles of the Reigns of Stephen, Henry II and Richard I, ed. Richard HowletT, London, Longman (Rolls Series 82), vol. 2, 1885 , p. 589-762.

\section{Studies}

Aurell, Martin, L'Empire des Plantagenêt (1154-1224), Paris, Perrin, 2003.

Aurell, Martin, La légende du roi Arthur, 550-1250, Paris, Perrin, 2007.

Aurell, Martin, "Henry II and Arthurian Legend", in Henry II: New Interpretations, Christopher HARPER-BILl and Nicholas Vincent (eds), Woodbridge, Boydell \& Brewer, 2007, p. 365-394.

Bezzola, Reto, Les origines et la formation de la littérature courtoise en Occident (5001200), $3^{\mathrm{e}}$ partie, La société courtoise: littérature de cour et littérature courtoise, 2 vol., Paris, Champion, 1963.

Boitani, Piero, Bologna, Corrado, Cipolla, Adele, Liborio, Mariantonia (dir.), introduzione di Peter Dronke, Alessandro nel Medioevo occidentale, Milano, Mondadori, 1997 (Fondazione Lorenzo Valla, Scrittori Greci e Latini).

51. Chronicles of the Reigns..., p. lxxix; TATLOCK, 1933b, p. 123-124 and HARRIs, 1994, p. 123. TATLOCK (1933b, p. 124-125) even considers the possibility that the idea of Arthur's letter was suggested by Henry II, as happened with Arthur's grave in Glastonbury, when Henry advised the monks where to look for Arthur's grave. On Henry II and the Arthurian Legend see also Aurell, 2007b. 
Boutet, Dominique, Charlemagne et Arthur, ou le roi imaginaire, Paris, Champion (Nouvelle bibliothèque du Moyen Âge, 20), 1992.

CARey, John, "Ireland and the Antipodes: The Heterodoxy of Virgil of Salzburg", Speculum, 64, 1, 1989, p. 1-10.

Chauou, Amaury, L'idéologie Plantagenêt. Royauté arthurienne et monarchie politique dans l'espace Plantagenêt, XII ${ }^{e}$-XIII ${ }^{e}$ siècles, Rennes, PUR, 2001.

DAy, Mildred Leake, “The Letter from King Arthur to Henry II: Political Use of the Arthurian Legend in Draco Normannicus", in The Spirit of the Court. Selected Proceedings of the Fourth Congress of the International Courtly Literature Society (Toronto, 1983), Glyn Sheridan Burgess and Robert Allen TAYlor (eds), Cambridge, Brewer, 1985, p. 153-157.

ECHARD, Siân, Arthurian Narrative in the Latin Tradition, Cambridge, Cambridge University Press, 1998.

Everard, Judith Ann, Brittany and the Angevins. Province and Empire 1158-1203, Cambridge, Cambridge University Press (Cambridge Studies in Medieval Life and Thought, 48), 2000.

Genette, Gérard, Palimpsests. Literature in the Second Degree, trans. Channa Newman and Claude Doubinsky, Lincoln and London, University of Nebraska Press, 1997 (original edition: Palimpsestes. La littérature au second degré, Paris, Éditions du Seuil, 1982).

Gransden, Antonia, Historical Writing in England: c. 500 to c. 1307, London, Routledge and Kegan Paul, 1974.

Greene, Virginie, "Qui croit au retour d'Arthur?", Cahiers de civilisation médiévale, 45, 2002, p. 321-340.

HARris, Irene, “Stephen of Rouen's Draco Normannicus: a Norman Epic”, in The Epic in History, Lola Sharon Davidson, Soumyendra Nath MukherjeE, Zvinka Zoe Zlatar (eds), Sydney, Sydney Association for Studies in Society and Culture (Sydney Studies in Society and Culture, 11), 1994, p. 112-124.

Krappe, Alexander Haggerty, “Antipodes”, Modern Language Notes, 59, 7, 1944, p. 441-447.

Kunl, Elizabeth, "Time and identity in Stephen of Rouen's Draco Normannicus", Journal of Medieval History, 40, 2014, p. 421-438.

Loomis, Roger Sherman, "King Arthur and the Antipodes", Modern Philology, 38, 3, 1941, p. 289-304.

Manitius, Maximilianus, Geschichte der lateinischen Literatur des Mittelalters, München, C.H. Beck, III, 1931.

Moretti, Gabriella, "Re Artù agli Antipodi”, in Relazioni di viaggio e conoscenza del mondo fra Medioevo e Umanesimo, Atti del $5^{\circ}$ Convegno internazionale di Studi dell'Associazione per il Medioevo e l'Umanesimo Latini, Columbeis 5 , Genova, 12-15 dicembre 1991, Stefano Pittaluga (ed.), Genova, Dipartimento di archeologia, filologia classica e loro tradizioni (Pubblicazioni del D.AR.FI.CL.ET. Nuova serie, 150), 1993, p. 441-450.

Pioletti, Antonio, “Artù, Avallon, l’Etna”, Quaderni Medievali, 28, 1989, p. 6-35.

Tatrock, John Strong Perry, "Geoffrey and King Arthur in Normannicus Draco", Modern Philology, 31, 1, 1933a, p. 1-18. 
Tatrock, John Strong Perry, "Geoffrey and King Arthur in Normannicus Draco (Concluded)”, Modern Philology, 31, 2, 1933b, p. 113-125.

Terlizzi, Francesco Paolo, "Harold, il re scomparso", in Il principe inVisibile, Atti del Convegno Internazionale di Studi (Mantova 27-30 novembre 2013), Lucia Bertolini, Arturo Calzona, Stefano Caroti and Glauco Maria Cantarella (eds), Turnhout, Brepols, 2015, p. 479-490.

VAN Houts, Elisabeth, "Latin and French as Languages of the Past in Normandy during the Reign of Henry II: Robert of Torigni, Stephen of Rouen and Wace", in Writers of the Reign of Henry II - Twelve Essays, Ruth Kennedy and Simon Meecham-Jones (eds), New York, Basingstoke, Palgrave Macmillan (The New Middle Ages), 2006, p. 53-77. 